Aurel Nuro*, Elda Marku, Bledar Murtaj

Tirana University, Faculty of Natural Sciences, Department of Chemistry, Tirana, Albania
Scientific paper

ISSN 0351-9465, E-ISSN 2466-2585

UDC:628.4.042(496.5)

doi: $10.5937 /$ ZasMat1703385N

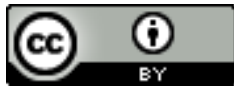

Zastita Materijala 58 (3)

$385-393(2017)$

\title{
Organic pollutants in water samples of Vjosa river - Albania
}

\begin{abstract}
The findings reported here belong to a study on determination of organochlorine pesticides, their residues, polychlorinated biphenyls, polyaromatic hydrocarbons and BTEX concentrations in water samples of Vjosa River (Albanian part). The Vjosa River in Albania is one of Europe's last living wild rivers. Water samples were taken in 12 stations starting from Sarandoporo (Leskovik, Kolonje) to Vjosa river mouth (Adriatic Sea), in March 2017. Organochlorine compounds and PCB markers were extracted using liquid-liquid technique using n-hexane as extracting solvent. PAHs were extracted also using liquid-liquid technique using dichloromethane as extracting solvent. After extraction the organic phase was dried with $\mathrm{Na}_{2} \mathrm{SO}_{4}$ anhidrous, for removing water. A Florisil column was used for the sample clean-up. After the concentration to $1 \mathrm{ml}$, the samples were injected in Varian 450 GC equiped with ECD and FID detectors. BTEX were extracted using HS/SME technique with PDMS fiber. Found data shown persistent levels of pesticides and their metabolites in water samples because their previous use. PCBs, PAHs and BTEX were found also for all samples. Their presence could be because of anthropogenic and automobilist impact in waters of Vjosa River. The found levels for organic pollutants in waters of Vjosa River were lower than reported levels for other ecosystems in Albania.
\end{abstract}

Keywords: Vjosa River, organochlorine pesticides, PCB, PAH, BTEX, water samples, GC/ECD/FID

\section{INTRODUCTION}

Albania is a country rich in water. The major water resource is surface water; most important are the rivers of Drini, Mati, Ishmi, Erzeni, Shkumbini, Semani, Vjosa and Bistrica. Vjosa River in Albania is one of Europe's last living wild rivers. Along its entire course of over 270 kilometers it is untamed and free flowing and characterized by beautiful canyons, braided river sections, islands, oxbows and meandering stretches. In some areas the riverbed expands over more than $2 \mathrm{~km}$ in width. The main source of the Vjosa River is in Greek territory near the village of Vouvoussa (the ancient name of Vjosa). On its first 80 kilometres the river flows through Greece and is named Aoos. In Albania it turns into Vjosa. The meandering lower part opens up into a valley with extensive wetlands, providing habitats for spawning fish, migratory birds and others.

\footnotetext{
${ }^{*}$ Corresponding author: Aurel Nuro

E-mail: aurel.nuro@fshn.edu.al

Paper received: 01. 07. 2017.

Paper accepted: 22. 07. 2017.

Paper is available on the website: www.idk.org.rs/journal
}

Finally, it drains into the sea just north of the Narta lagoon - one of the biggest and ecologically richest lagoons of Albanian and as such designated as Managed Nature Reserve. The Vjosa is draining a total area of $6,700 \mathrm{~km}^{2}$ in Albania and Greece and discharges an average of $204 \mathrm{~m}^{3} / \mathrm{s}$ into the Adriatic Sea [2, 3].

Organochlorinated pesticides (OCPs) and polychlorinated pesticides (PCBs) are a group of compounds of great chemical stability and persistence whose presence in the environment is a clear indication of anthropogenic pollution [1]. The massive use of pesticides for agricultural purposes caused their widespread diffusion to all environmental compartments including a wide range of organisms up to the humans. Before 90' organochlorine pesticides were used widely in Albania for agricultural purposes. The main agricultural areas were in the western of the country but almost every were in the country had been developed different directions of agricultural (fruits, corns, vegetables, etc). The most used organochlorinated pesticides were DDT, Lindane, HCB, Aldrins and Heptachlors. Commercial PCB mixtures were used in a wide variety of applications. They are chemically highly stable, lipophilic compounds and resist microbial, photochemical, chemical and thermal degradation 
[4,5]. In Albania PCBs are used mainly in transformer oils after 90', but the source of pollution is mostly airborne origin with predominance of most volatile PCB congeners like Aroclor 1240, 1254 $[10,11]$. Polyaromatic hydrocarbons are a large group of compounds with a molecular structure that includes two or more fused aromatic rings. They are widely distributed in the environment as a result of the incomplete combustion of organic materials, both of natural (e.g. forest fires) and anthropogenic sources (e.g. motor vehicles, industrial processes,). The spillage of fossil fuel can be a significant source of contamination, as well as the leaching from pipes. The occurrences in the environment and their proved mutagenicity and carcinogenicity, sixteen PAH have been selected by the US EPA ("United States Environmental Protection Agency) as priority pollutants $[6,7,16]$. Benzene, Toluene, Ethylbenzene and Xylenes (BTEX) are also major constituents of gasoline. Exhaust emissions from vehicles, as well as evaporative losses from gasoline stations and vehicles, are major sources of BTEX that are released in the atmosphere. Benzene and other monocyclic hydrocarbons were found to be problematic for the environment and the humans (WHO/IARC, 1987). There are many different techniques by which organic compounds in water samples can be measured, including gas chromatography with mass spectrometry [4,7-9].

\section{MATERIALS AND METHOD}

\subsection{Sampling of water samples in Vjosa River}

Water samples were taken in 12 stations starting from Sarandoporo (Leskovik, Kolonje) to Vjosa rivermouth (Adriatic Sea). Water samples were taken in March 2017. The sampling stations were presented in Figure 1. $2 \mathrm{~L}$ of water were taken from each station in Teflon bottles. The sampling method based on UNEP/MED Wg. 128/2, 1997. Water samples were tranported and conserved in $+4^{\circ} \mathrm{C}$ prior to their analyze.

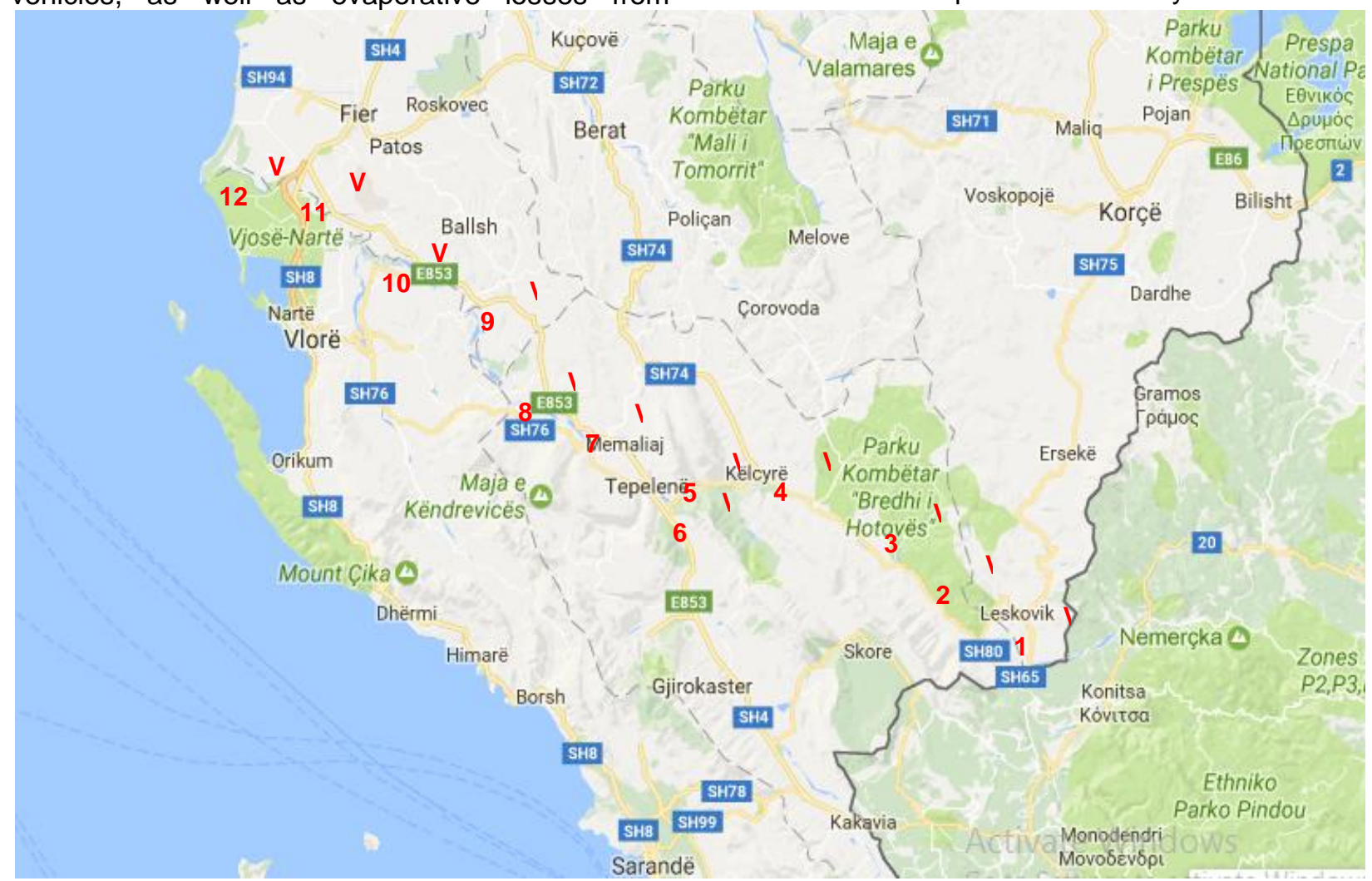

Figure 1. Sampling stations in Vjosa River

Slika 1. Mesta za uzorkovanje u reci Vjosa

\subsection{Chemicals}

$\mathrm{n}$-Hexane, dichloromethane of special grade for pesticide residue analysis were purchased from Sigma Aldrich. Anhydrous sodium sulfate $\left(\mathrm{Na}_{2} \mathrm{SO}_{4}\right)$, Florisil ( $\geq 400$ mesh ASTM) and silica gel (60-100 mesh ASTM) were purchased also from Sigma Aldrich. $\mathrm{H}_{2} \mathrm{SO}_{4}$ with $95-97 \%$ purity for
GC analyses was purchased by Merck. The sodium sulfate, florisil and silica gel were preextracted with hexane/dichloromethane (4/1) in a Soxhlet extractor, dried and were rinsed with hexane/dichloromethane (4/1) just before utilization. All glassware was rigorously cleaned with detergent followed by pyrolysis at $300^{\circ} \mathrm{C}$. 


\section{3. $G C / E C D$ analyze of organochlorine pesticides (EPA 8081A) and PCB markers in water samples}

Liquid-liquid extraction was used for the extraction of organochlorine pesticide residues and polychlorinated biphenyls from water samples of Vjosa River. $1 \mathrm{~L}$ of water, $10 \mu \mathrm{l} \mathrm{PCB}-29$ as internal standard and $20 \mathrm{~mL}$-hexane as extracting solvent were added in a separatory funnel. After extraction the organic phase was dried with $5 \mathrm{~g} \mathrm{Na}_{2} \mathrm{SO}_{4}$ anhidrous for water removing. A Florisil column was used for the sample clean-up. After the concentration to $1 \mathrm{ml}$, the samples were injected in GC/ECD HP 6890 Series II. Procedural blanks were regularly performed and all results presented are corrected for blank levels. Rtx-5 capillary column $(30 \mathrm{~m} \times 0.33 \mathrm{~mm} \times 0.25 \mu \mathrm{m})$ was used to isolate and determine simultaneously organochlorine pesticides (based on EPA 8081A method) and 7 PCB markers. EPA 8081A Mixture and 7 PCB markers was used for qualitative and quantitative of chlorinated pollutants analyse. Splitless injection was made for 2 ul sample. Injector temperature was held at $280^{\circ} \mathrm{C}$. ECD temperature was held at $300^{\circ} \mathrm{C}$. Helium was used as carrier gas with $1 \mathrm{ml} / \mathrm{min}$. Nitrogen was used as make-up gas with $25 \mathrm{ml} / \mathrm{min}$. Quantification of chlorinated pollutants was based on external standards. Five points of calibration were selected for chlorinated pollutants to concentrations $10,20,50,100$ and $250 \mathrm{ng} / \mathrm{L}[4-6,8,13,14]$.

\subsection{GC/FID determination of PAHs in water samples of Vjosa River}

PAHs were extracted using liquid-liquid extraction (LLE) assisted with Dichloromethane solvent. $1 \mathrm{~L}$ of water and $20 \mathrm{ml}$ Dichloromethane as extract solvent was added in a separatory funel. After shaking organic phase was collected in a beker when was added $5 \mathrm{~g} \mathrm{Na}_{2} \mathrm{SO}_{4}$ anhidrous for removing water. After concentration in $1 \mathrm{ml}$ Dichloromethane, the samples were injected directly to GC/FID for PAH analyze.

Gas chromatographic analyses were realized with a Varian 450 GC instrument equipped with a flame ionization detector and PTV detector. VF$1 \mathrm{~ms}$ capillary column $(30 \mathrm{~m} \times 0.33 \mathrm{~mm} \times 0.25 \mu \mathrm{m})$ was used to isolate and determine $13 \mathrm{PAHs}$ compounds. Helium was used as carrier gaz with 1 $\mathrm{ml} / \mathrm{min}$. EPA 525 Mixture was used for qualitative and quantitative of PAH analyse. FID temperature was held at $280^{\circ} \mathrm{C}$. Nitrogen was used as carrier and make-up gas for both analyses. Hydrogen and air were flame detector gases with $30 \mathrm{ml} / \mathrm{min}$ and $300 \mathrm{ml} / \mathrm{min}$, respectively. Quantification of $\mathrm{PAH}$ was based on external standards. Three points of calibration were selected for $\mathrm{PAH}$ after diluted in dichloromethane to concentrations 20,50 and 100 $\mu g / L[11,15,16]$.

\subsection{HS/SME-GC/FID analyze of BTEX in water samples of Vjosa River}

Headspace solid phase micro extraction (HSSPME) technique was used to trace BTEX in water samples. $5.0 \mathrm{~mL}$ of water sample was placed in a $10 \mathrm{~mL}$ headspace vial (5 replicate vials for each sample) to adsorb BTEX. The vials were placed in a heating block for $45 \mathrm{~min}$ at $50^{\circ} \mathrm{C}$. Extraction of volatile compounds was done using a $100 \mu \mathrm{m}$ Polydimethylsiloxane fibre in a SPME manual holder. Direct injection in HS mode was performed in $280^{\circ} \mathrm{C}(20 \mathrm{sec})$ in a PTV injector. Helium was used as carrier gas in constant flow mode with 0.8 $\mathrm{ml} / \mathrm{min}$. FID temperature was held at $280^{\circ} \mathrm{C}$. Quantification of BTEX was based on external standards. Three calibration points were selected with 10,25 and $50 \mu \mathrm{g} / \mathrm{L}$ for BTEX. The method used for determination of VOCs in water samples by capillary GS was optimized for the duration and temperature of extraction, and GC parameters [9, $11,15]$.

\section{RESULTS AND DISCUSSION}

Figure 2 show the total of organochlorine pesticides in water samples of Vjosa River, March 2017. The higher concentration was for V12 station, near rivermouth of Vjosa River (Adriatic Sea) with $102.3 \mathrm{ng} / \mathrm{L}$. For the $50 \%$ of the stations (V1, V2, V3, V5, V6 and V9) the levels of organochlorine pesticides were lower than $5 \mathrm{ng} / \mathrm{L}$. The average level of organochlorine pesticides and their residues was $20.01 \mathrm{ng} / \mathrm{L}$. The found level could be mostly because of punctual sources because of differences between the stations. Other factor could be the water flow in first part of the river (Albanian part) the rate of flow is higher than in the second part of the river. Also, in the second part the river run through enormous agricultural areas.

There are many drainage and irrigation canals that can affect new pesticide inflows into waters of Vjosa River. The distribution of organochlorinated pesticides (Figure 2) in water samples of Vjosa River was almost the same for all stations because the origin of pollution is the same. It was noted that some pesticides were in higher levels for some stations. This could be because of punctual sources or new arrivals from different effluents and drainage canals of agricultural areas. Profile of organochlorine pesticides (Figure 3) were: DDTs $>\mathrm{HCHs}$ $>$ Mirex > Aldrines. Profile of pesticides was connected with individual levels in different sampling stations. For example, DDD was detected in $12 \%$ of water samples; only for one station its level was high. The same was for alfa- $\mathrm{HCH}$ and Mirex.

$\mathrm{HCH}$ s were in found in low level almost for all samples. Exception was only for V12 sample with maximal concentration $(45.4 \mathrm{ng} / \mathrm{L})$. This could be because a punctual source in this part of the river. Lindane was found in lower level in $25 \%$ of water 
samples. Profiles of $\mathrm{HCHs}$ were: Alfa-HCH > delta$\mathrm{HCH}>$ Lindane > epsilon- $\mathrm{HCH}>$ beta- $\mathrm{HCH}$. Total of $\mathrm{HCHs}$ were lower than permitted level $(20 \mathrm{ng} / \mathrm{L})$ for surface waters conform Directive 2008/105/EC. Levels of cyclopentadienyl pesticides (Heptachlor, Chlordane and related compounds) were in range $0.2 \mathrm{ng} / \mathrm{L}$ to $3.1 \mathrm{ng} / \mathrm{L}$. Chlordane cis was found in higher level in V8 sample. The higher levels were found for their degradation products (heptachlor epoxides and oxychlordane). Their profile were: Chlordane cis + trans > Heptachlor epoxides cis + trans > Heptachlor > oxychlordane. Total of Heptachlors and total of chlordanes were lower than permitted level $(10 \mathrm{ng} / \mathrm{L})$ for surface waters conform Directive 2008/105/EC. Aldrines levels were from $0.2 \mathrm{ng} / \mathrm{L}$ to $8.8 \mathrm{ng} / \mathrm{L}$. Aldrin was found in high level in V1 and V4 samples. Profile of Aldrines were: Aldrin > Endrin > Izodrin > Dieldrin. Total of Aldrins were lower than permitted level $(10 \mathrm{ng} / \mathrm{L})$ for surface waters conform Directive 2008/105/EC. Endosulfanes levels were found from $0.4 \mathrm{ng} / \mathrm{L}$ to $1.5 \mathrm{ng} / \mathrm{L}$. Profile of endosulfanes were: Endosulfan beta $>$ Endosulfan alfa $>$ Endosulfan sulfat. Total of Endosulfanes were lower than permitted level (5 $\mathrm{ng} / \mathrm{L})$ for surface waters conform Directive 2008/105/EC. DDT levels were from $0.1 \mathrm{ng} / \mathrm{L}$ to $44.4 \mathrm{ng} / \mathrm{L}$. 4,4-DDD concentration was found in high level in V7 sample. Higher levels were found for DDT metabolite. DDT was found in $10 \%$ of water samples. DDT could be found because of their previous use in agricultural areas near the river or because a punctual source. Profile of DDTs were: DDD > DDE > DDT > Methoxychlor > Dikofol. Total of DDTs were lower than permitted level (25 ng/L); DDT concentration was lower than permited level (10 $\mathrm{ng} / \mathrm{L})$ for surface waters conform Directive 2008/105/EC. Mirex dhe Chlordekon were found only in 2 samples. Concentration of Mirex was higher in rivermouth of Vjosa River. This fact could be because of new arrivals from water irrigation or the influence of Adriatic Sea currents. Organochlorine pesticides are not used anymore right after the 90' in Albania. These data shown persistent levels of pesticides and their metabolites in water samples because their previous use. The found levels for organochlorinated pesticides in waters of Vjosa River were lower than reported levels for other ecosystems in Albania.

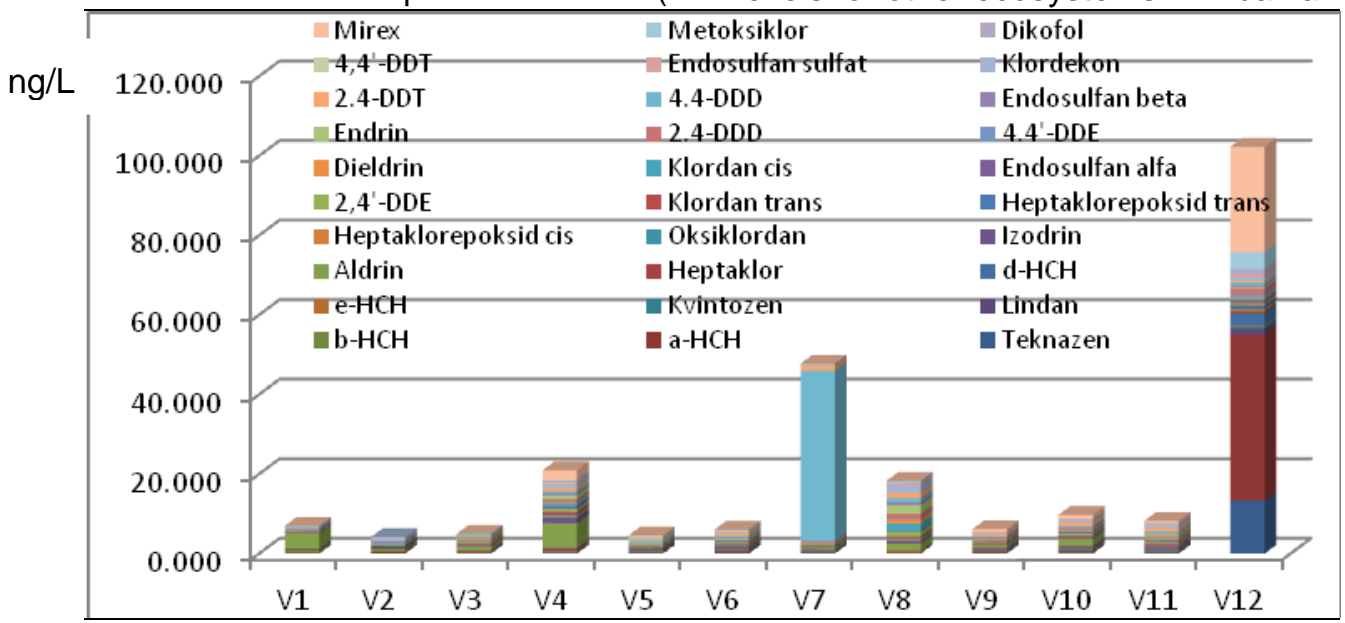

Figure 2. Total of organochlorine pesticides in water samples of Vjosa River Slika 2. Ukupna količina organohlornih pesticida u uzorcima vode reke Vjosa

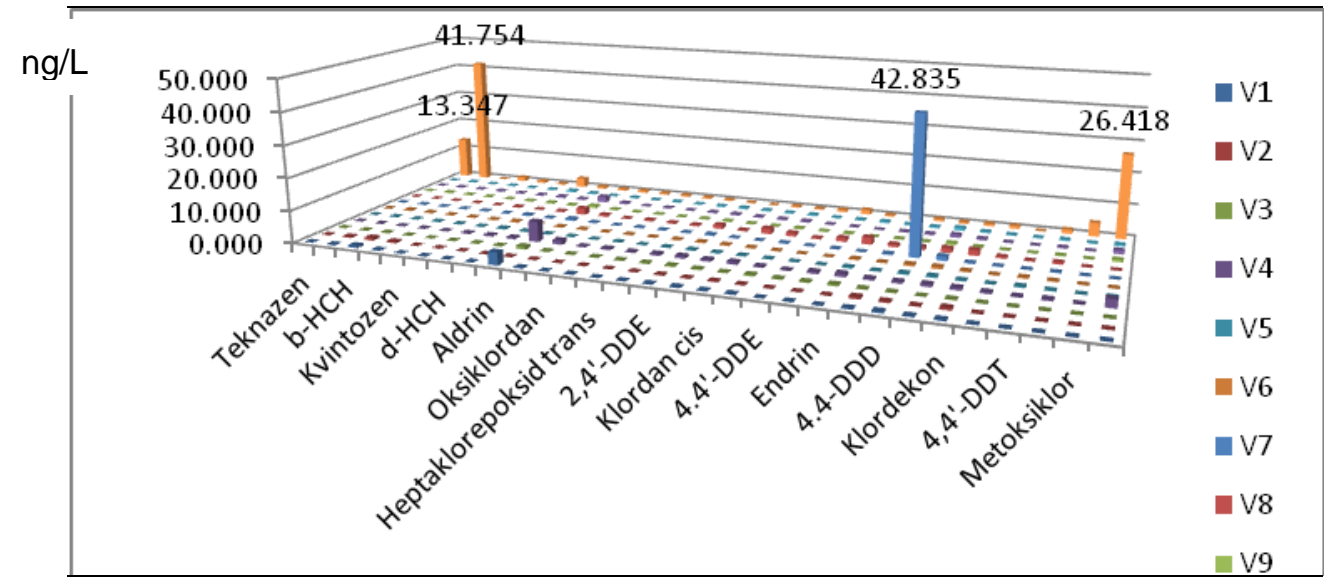

Figure 3. Distribution of organochlorine pesticides

Slika 3. Distribucija organohlornih pesticida 


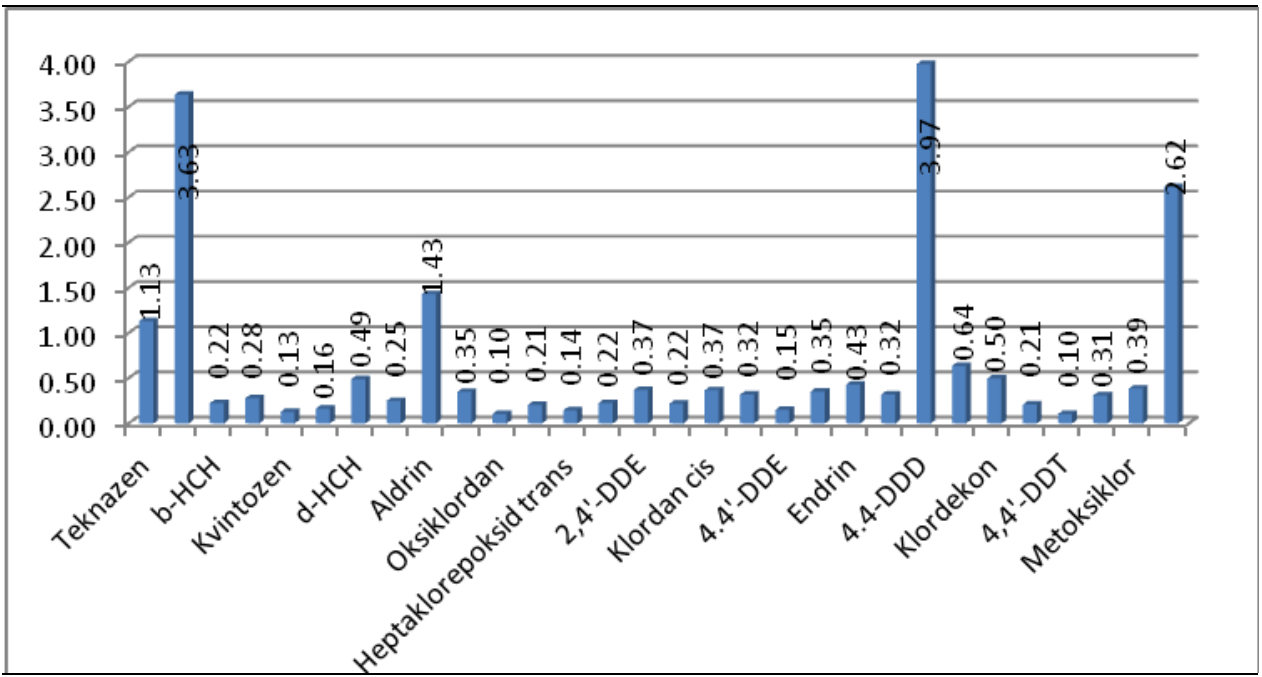

Figure 4. Profile of organochlorine pesticides in water samples

\section{Slika 4. Sastav organohlornih pesticida u uzorcima vode}

Figure 5 show the total of PCB markers in water samples of Vjosa River, March 2017. The hidher level was for V 4 station with $15.9 \mathrm{ng} / \mathrm{L}$. PCB markers were found lower than $2 \mathrm{ng} / \mathrm{L}$ in $\mathrm{V} 1$, V2, V3 and V7 stations. Distribution of PCBs (Figure 6) were almost the same with distribution of pesticides because the same properties. Distributions of PCBs were the same for all samples. This could be because the same origin of pollution for PCBs in water of Vjosa River. PCB 194 was found in higher level for V4, V5, V9 and V11 stations. PCB 180 was found in high level in V8 station. PCB 194 and PCB 180 are heavy congeners of PCBs. Their origin could be terrestrial. Profiles of PCBs (Figure 7) were: PCB $194>$ PCB $138>$ PCB $52>$ PCB 118. The levels of PCBs in waters of Vjosa Rivers were lower than reported levels for other water ecosystems in Albania (Como et al, 2010; Neziri et al, 2013; Nuro et al, 2014) but the profile of PCBs was different. For other studies the higher levels were for volatile PCBs. This profile could be because of punctual sources in water flows. Discharging of wastes from industries and mechanical businesses could affect found level and their profile.

$\mathrm{ng} / \mathrm{L}$

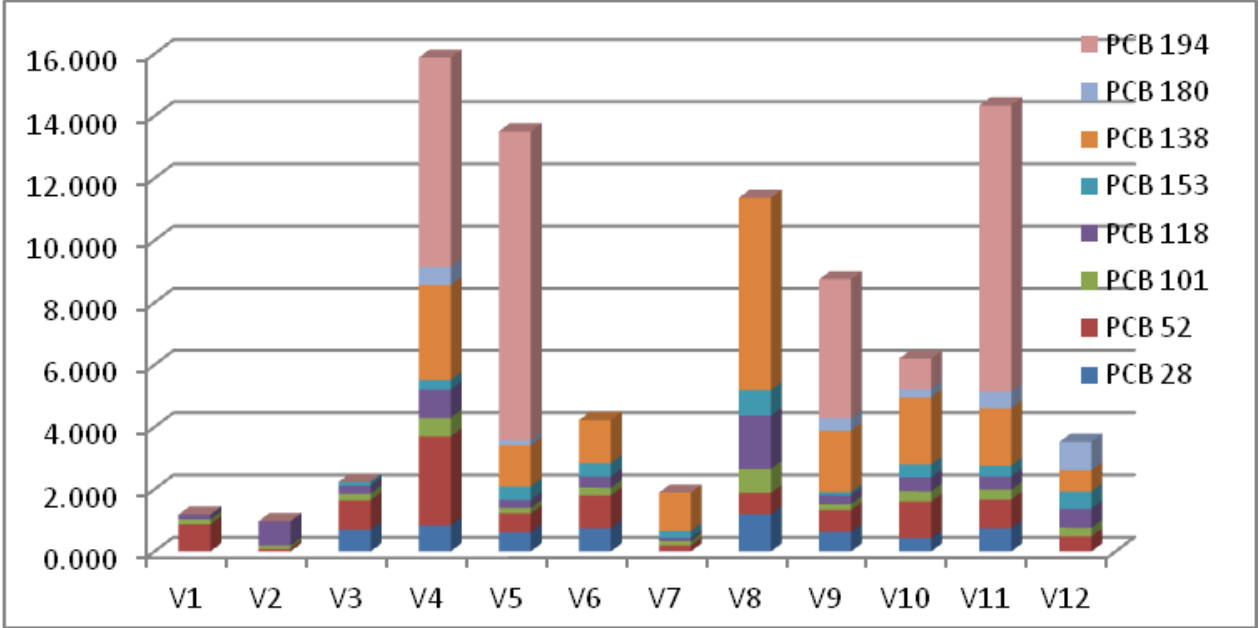

Figure 5. Total of PCB markers in water samples of Vjosa River Slika 5. Ukupno PCB markera u uzorcima vode reke Vjosa

$\mathrm{PAHs}$ in water samples for each station of Vjosa River were shown in Figure 8. PAHs weren't detected for 11 water samples of Vjosa River, March 2017. PAHs were observed in V7 station with $0.14 \mu \mathrm{g} / \mathrm{L}$. It was noted the presence of Crysene for V7 sample. This could be connected with a punctual source because of direct discharging of waste industries. Automobilist transport near the river could be another factor. $\mathrm{PAH}$ levels in water samples of Vjosa River were lower than reported levels in other ecosystem in Albania [10, 11, 15]. Total of PAHs were lower than permitted level $(50 \mathrm{ng} / \mathrm{L})$ for surface waters conform Directive 2008/105/EC. 


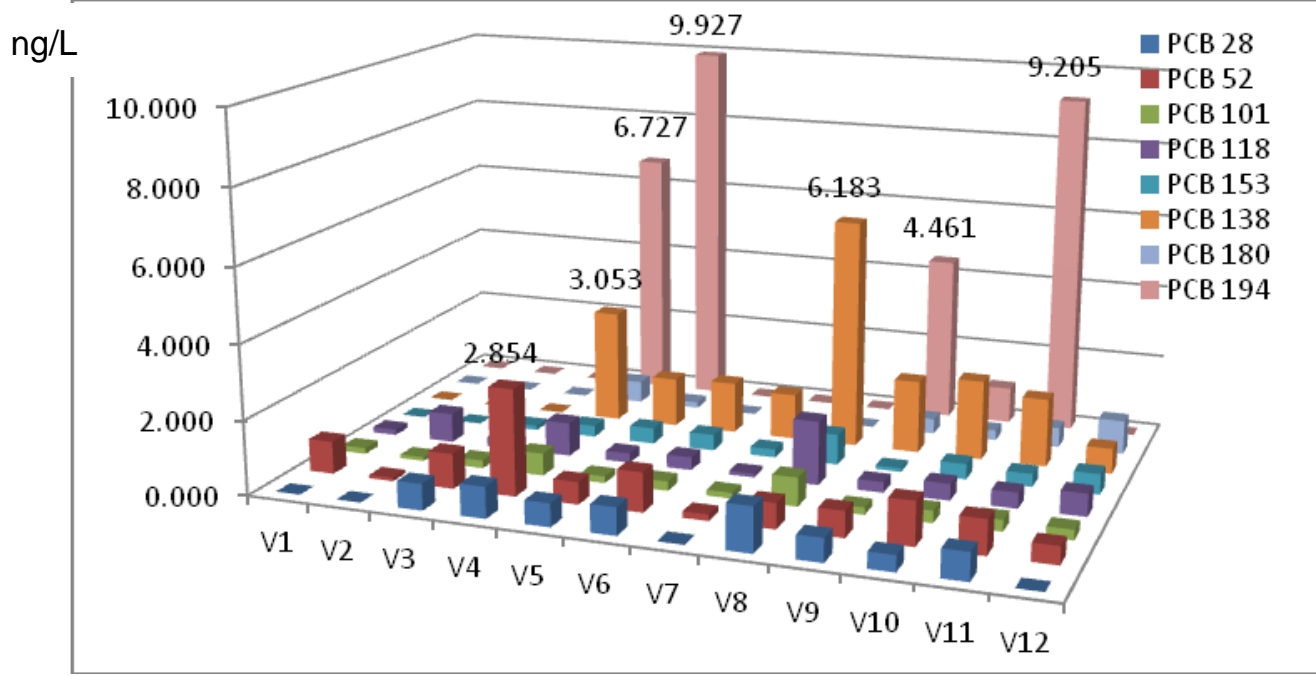

Figure 6. Distribution of PCB markers in water samples of Vjosa River Slika 6. Distribucija PSB marker u uzorcima vode reke Vjosa

$\mathrm{ng} / \mathrm{L}$

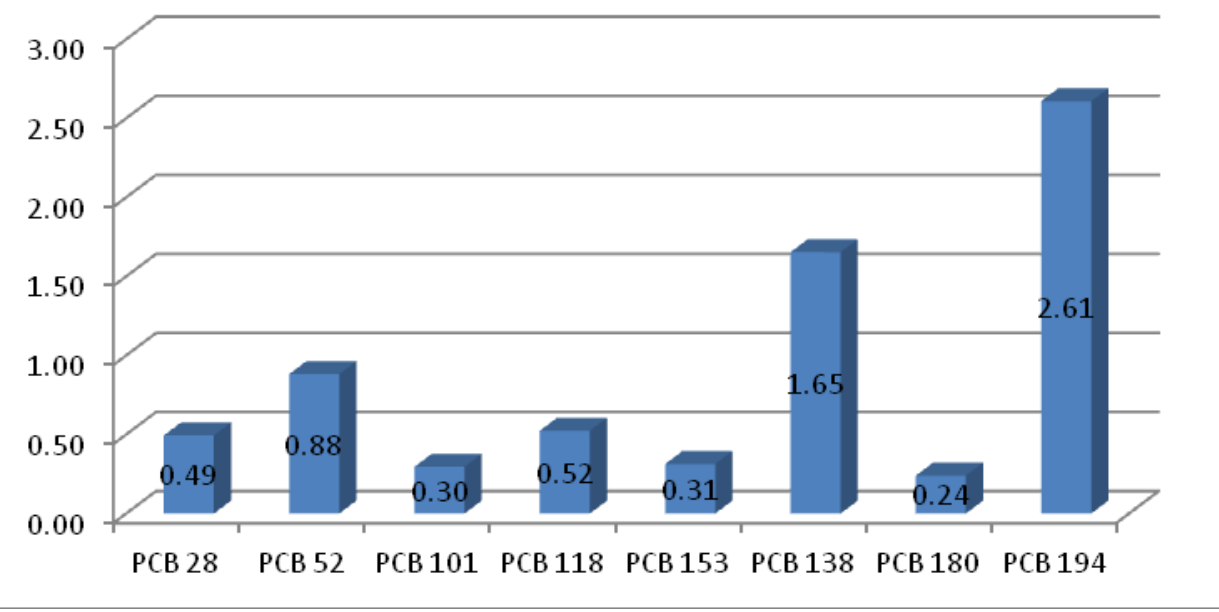

Figure 7. Profile of PCB markers

Slika 7. Sastav PSB markera

$\mu g / L$

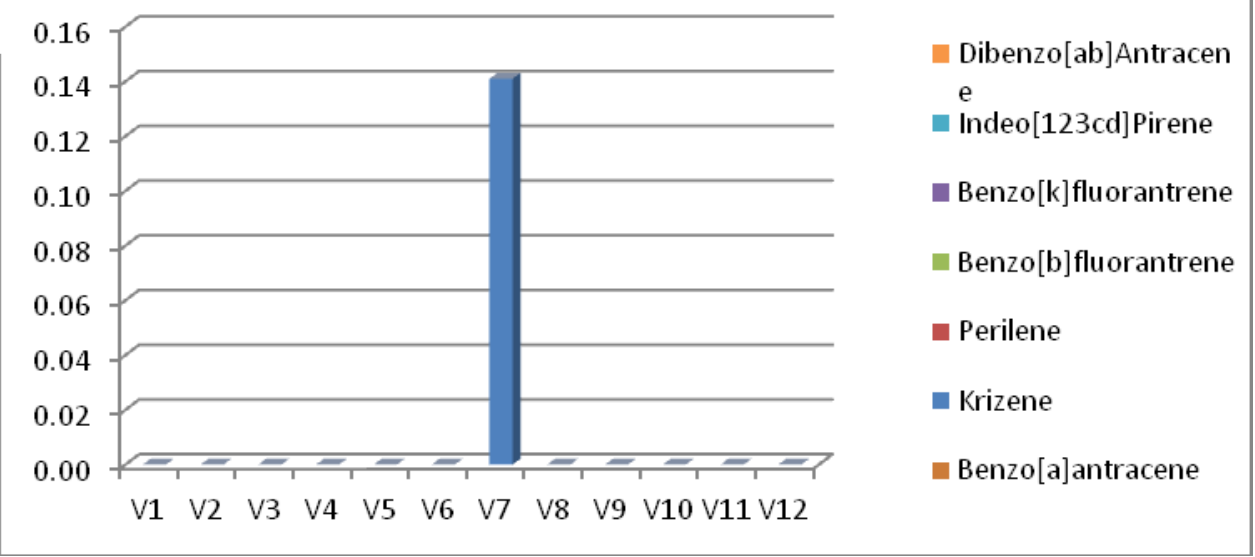

Figure 8. Total of PAHs in water samples of Vjosa River

Slika 8. Ukupno PAHs u uzorcima vode reke Vjosa

Total of BTEX in water samples for each of studied stations of Vjosa River was given in Figure
9. Stations V10, V11 and V12 9 were observed to have the maximum level with $26.45 \mu \mathrm{g} / \mathrm{L}$. BTEX 
weren't detected for water samples V1, V2, V3, V4, V5, V6 and V9. For all studied samples in Vjosa River the average level of BTEX were $4.8 \mu \mathrm{g} / \mathrm{L}$. BTEX presence in the water river can had the main factors natural inputs, automotive transport on roads near the Vjosa River. Direct discharges of some industries in to the river could be other factor. Distribution of BTEX in water samples taken in Vjosa River is shown in Figure 10.

$\mu g / L$

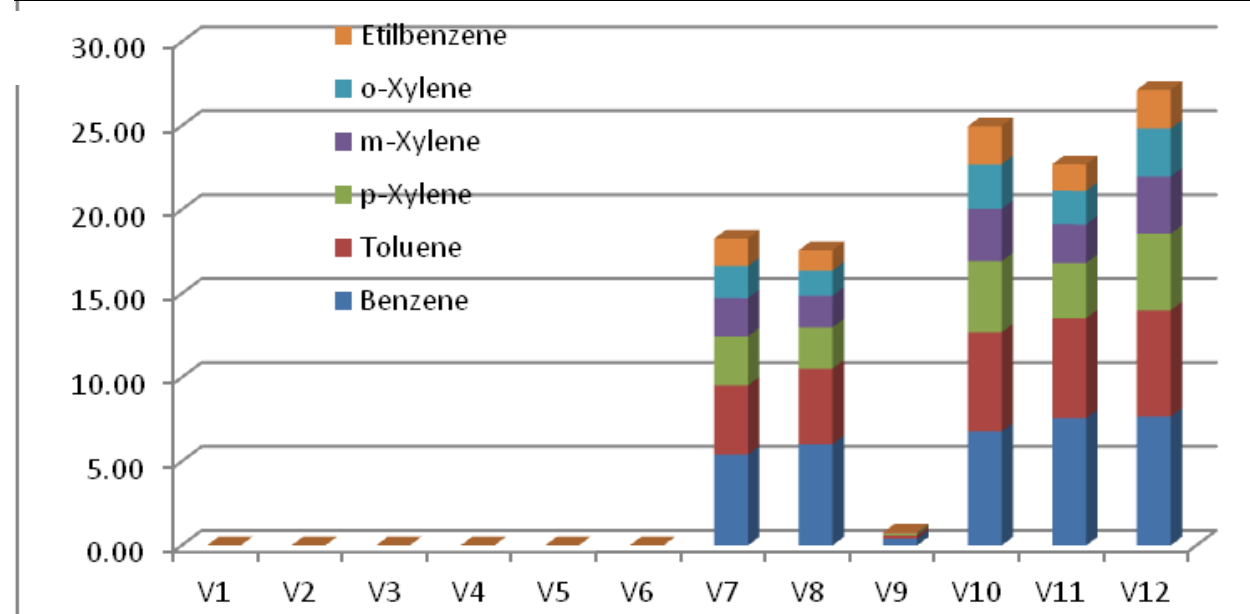

Figure 9. Total of BTEX in water samples of Vjosa River Slika 9. Ukupno BTEX u uzorcima vode reke Vjosa

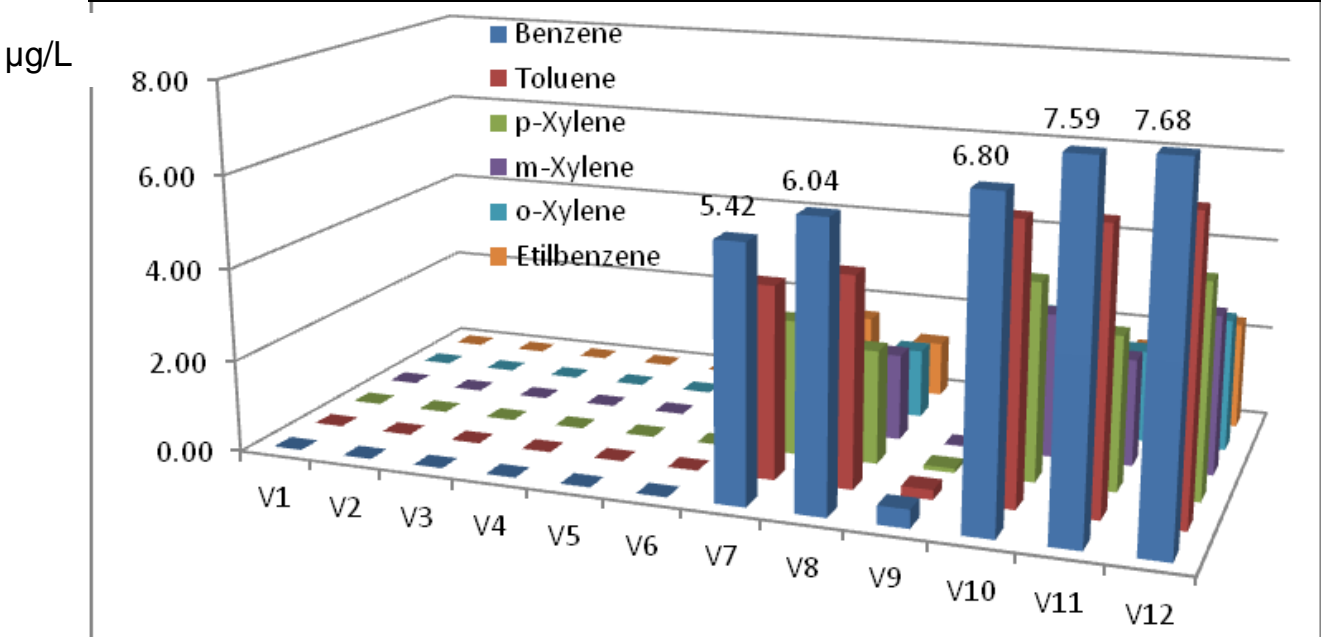

Figure 10. Distribution of BTEX in water samples Slika 10. Distribucija BTEX u uzorcima vode

$\mu \mathrm{g} / \mathrm{L}$

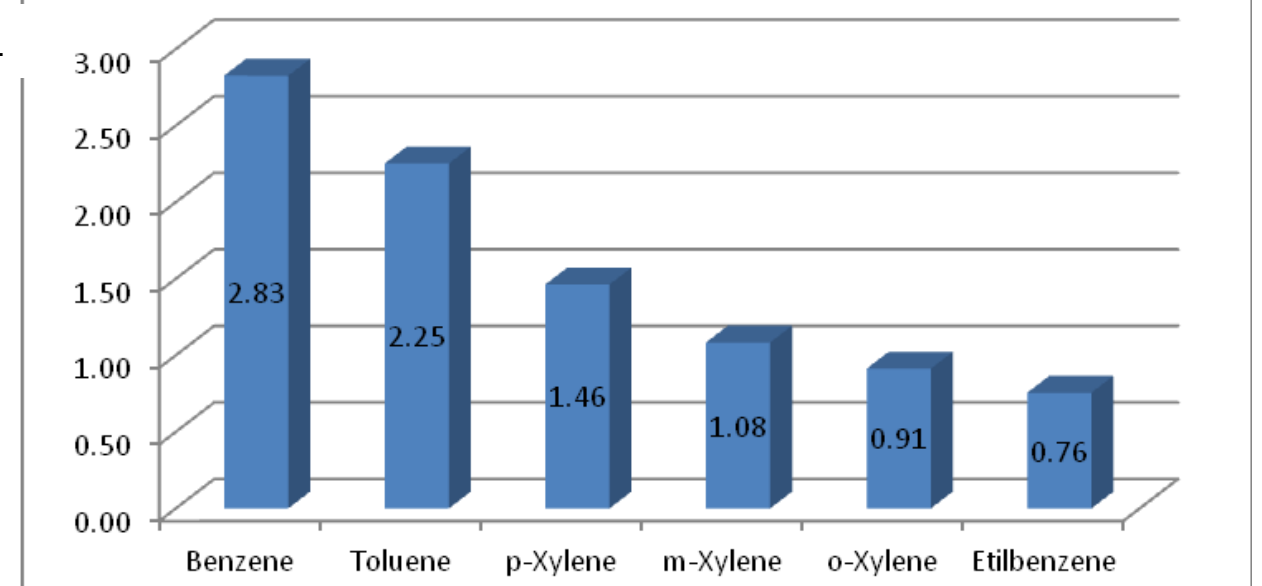

Figure 11. Profile of BTEX in water samples

Slika 11. Sastav BTEX u uzorcima vode 
BTEX were shown to have the same distribution because of the same pollution origin. Profile of BTEX $(\mu \mathrm{g} / \mathrm{L})$ in water samples taken in Vjosa River (Figure 11) were: Benzene $>$ Toluene $>$ Xylenes > Ethylbenzene. Levels and distribution of BTEX could be because of discharges for several industries, car servicing, urban water and automobilist road near the river. BTEX levels in water samples of Vjosa River were the same than reported levels in other ecosystem in Albania [11, 15]. Benzene concentration was lower than permitted level $(10 \mathrm{ng} / \mathrm{L})$ for surface waters conform Directive 2008/105/EC.

\section{CONCLUSIONS}

Determination of organochlorine pesticides, their residues, polychlorinated biphenyls, $\mathrm{PAH}$ and BTEX was realized in water samples of Vjosa River (Albanian part). Water samples were taken in 12 stations starting in March 2017. GC/ECD technique was used for determination of organochlorine pollutants. PAHs and BTEX were determined by using GC/FID technique. The average level of organochlorine pesticides in water samples of Vjosa River was $20.01 \mathrm{ng} / \mathrm{L}$. The found level could be mostly because of punctual sources because of differences between the stations. Other factor could be the water flow in first part of the river (Albanian part) the rate of flow is higher than in the second part of the river. Also, in the second part the river run through enormous agricultural areas. There are many drainage and irrigation canals that can affect new pesticide inflows into waters of Vjosa River. It was noted that some pesticides were in higher levels for some stations.

This could be because of punctual sources or new arrivals from different effluents and drainage canals of agricultural areas. Profile of organochlorine pesticides were: DDTs $>\mathrm{HCHs}>$ Mirex > Aldrines. Profile of pesticides was connected with individual levels in different sampling stations. For example, DDD was detected in $12 \%$ of water samples; only for one station its level was high. The same was for alfa$\mathrm{HCH}$ and Mirex. Organochlorine pesticides are not used anymore right after the 90' in Albania. These data shown persistent levels of pesticides and their metabolites in water samples because their previous use. PCB markers were found in $50 \%$ of studied stations lower than $2 \mathrm{ng} / \mathrm{L}$. Distribution of PCBs were almost the same with distribution of pesticides because the same properties. PCB 194 was found in higher level for four stations. PCB 180 was found in high level in V8 station. PCB 194 and PCB 180 are heavy congeners of PCBs. Their origin could be terrestrial. Profiles of $\mathrm{PCBs}$ were: PCB $194>$ PCB $138>$ PCB $52>$ PCB 118. PCB markers levels and profile could be because of punctual sources in water flows. Discharging of wastes from industries and mechanical businesses could affect found level and their profile. PAHs weren't detected for 11 water samples of Vjosa River. It was noted the presence of Crysene for V7 sample. The presence of Crysene only for one sample could be connected with a punctual source because of direct discharging of waste industries. BTEX weren't detected for water samples V1, V2, V3, V4, V5, V6 and V9. For all studied samples in Vjosa River the average level of BTEX were 4.8 $\mu \mathrm{g} / \mathrm{L}$. BTEX presence in the water river can had the main factors natural inputs, automotive transport on roads near the Vjosa River. Direct discharges of some industries directly in the river could be other factor. Profile of BTEX $(\mu \mathrm{g} / \mathrm{L})$ in water samples taken in Vjosa River (Figure 13) were: Benzene > Toluene > Xylenes > Ethylbenzene. Levels and distribution of PAH and BTEX could be because of discharges for several industries, car servicing, urban water and automobilist road near the river. The found levels for organic pollutants in waters of Vjosa River were lower than reported levels for other ecosystems in Albania. Individual concentrations of studied pollutants were lower than permitted level for surface waters based on Directive 2008/105/EC. PCBs, PAHs and BTEX were found also for all samples. Their presence could be because of anthropogenic and automobilist impact in waters of Vjosa River.

\section{REFERENCES}

[1] ATSDR (2000) Toxicological Profile for Polychlorinated Biphenyls (PCBs). US Department Of Health And Human Services, Public Health Service, Agency For Toxic Substances And Disease Registry, Atlanta, Georgia, USA.

[2] E.Como, A.Nuro, B.Murtajn, E.Marku, A.Emiri (2013) Study of Some Organic Pollutants in Water Samples of Shkumbini River", International Journal of Ecosystems and Ecology Sciences (IJEES), 8(4), 573-579.

[3] A.Çullaj, A.Hasko, A.Miho, F.Schanz, H.Brandl, R.Bachofen (2005) Overview on Albanian natural waters and the human impact, Environment International, 31(1), 133-146.

[4] Directive 2008/105/Ec Of The European Parliament And Of The Council on environmental quality standards in the field of water policy, amending and subsequently repealing Council Directives 82/176/EEC, 83/513/EEC, 84/156/EEC, 84/491/ EEC, 86/280/EEC and amending Directive 2000/60/ EC of the European Parliament and of the Council

[5] EU (2007) "Guidance Document On Pesticide Residue Analytical Methods", (ENV/JM/ ENV/JM/MONO (2007;17)

[6] Gustafson E., Dickhut M., (1997): Distribution of polycyclic aromatic hydrocarbons in southern Chesapeake Bay surface water: evaluation of three methods for determining freely dissolved water 
concentrations. Environment Toxicology Chemistry $16,452-461$

[7] I.K.Konstantinou, D.G.Hela, T.A.Albanis (2006) The status of pesticide pollution in surface waters (rivers and lakes) of Greece. Part I. Review on occurrence and levels, Environmental Pollution, 141(3), 555570.

[8] V.Lang (1992) Revieë: Polychlorinated Biphenyls In The Environment, Journal of Chromatography, 595, 1-43.

[9] Th.Lekkas, G.Kolokythas, A.Nikolaou, M. Kostopoulou, A.Kotrikla, G.Gatidou, N.S. Thomaidis, S.Golfinopoulos, C.Makri (2004) Evaluation of the pollution of the surface waters of Greece from the priority compounds of List II, 76/464/EEC Directive, and other toxic compounds, Environment International, 30(8), 995-1007.

[10] J.C.F.Menendéz, L.F.Sánchez, J.E.S.Uría, E.F. Martínez, A.Sanz-Medel (2000) Static headspace, solid-phase microextraction and headspace solidphase microextraction for BTEX determination in aqueous samples by gas chromatography, Anal Chim Acta, 415, 9-20.

[11] A.Neziri, E.Marku, A.Nuro (2010) Identification of Polychlorinated biphenyls in Shkodra Lake water using bottle sampling and passive sampling technology, Asian Journal of Chemistry, 22(10), 7850-7856.

[12] A.Nuro, E.Marku, B.Murtaj (2014) Determination of $\mathrm{PAH}$ and BTEX levels in water sampling using GC/FID technique. Case study: Patoku Lagoon, International Journal of Ecosystems and Ecology Science (IJEES), 4(2) 195-200.

[13] USEPA (2009) Method EPA 524. 3: Measurement of purgeable organic compounds in water by capillary column gas chromatography/mass spectrometry.

[14] Z.Vryzas, G.Vassiliou, C.Alexoudis, E. Papadopoulou-Mourkidou (2009) Spatial and temporal distribution of pesticide residues in surface waters in northeastern Greece, Water Research, 43(1),1-10.

[15] D.E.Wells, P.Hess (2000) Determination and evaluation of chlorinated biphenyls. In: Barceló $E$ (2007) Sample handling and trace analysis of pollutants, techniques, applications and quality assurance, Elsevier, Amsterdam; p.239-285.

[16] A.Nuro, E.Marku, B.Murtaj, V.Plaku (2017) Determination of Some Organic Pollutans In Water Rivers of Tirana City, Zaštita materijala, 58(2), 212-221.

\title{
IZVOD
}

\section{ORGANSKI ZAGAĐIVAČI U UZORCIMA VODE REKE VJOSA - ALBANIJA}

Ispitivanja koja su u ovom radu prikazana pripadaju studiji o određivanju organohlornih pesticida, njihovih ostataka, polihloriranih bifenila, aromatičnih ugljovodonika $i$ koncentracija BTEKS u uzorcima vode reke Vjosa (albanski dio). Reka Vjosa u Albaniji je jedna od poslednjih živih divljih reka u Evropi. Uzorci vode uzeti su na 12 mesta počevši od Sarandopora (Leskovik, Kolonje) do ulivanja reke Vjosa u Jadransko more, u mesecu martu 2017. godine. Organohloridna jedinjenja i PCB markeri su ekstrahovani tečnom-tečnom tehnikom, koristeći n-heksan kao ekstrakcioni rastvarač. PAH uzorci su ekstrahovani koristeći tehniku tečno-tečno, koristeći dihlormetan kao ekstrakcioni rastvarač. Nakon ekstrakcije organska faza je osušena sa $\mathrm{Na}_{2} \mathrm{SO}_{4}$ anhidrovanim, za uklanjanje vode. Za čišćenje uzorka korišćena je kolona Florisil. Nakon koncentrisanja do $1 \mathrm{ml}$, uzorci su injektirani u Varian 450 GC, opremljenim ECD i FID detektorima. BTEKS su ekstrahovani korišćenjem tehnike HS / SME sa PDMS vlaknom. Dobijeni podaci pokazuju razne koncentracije pesticida i njihovih metabolita u uzorcima vode zbog njihove prethodne upotrebe. PCB, PAH i BTEKS su pronađeni u svim uzorcima vode. Njihovo prisustvo može biti zbog antropogenih uticaja i uticaja saobraćaja na vodu reke Vjosa. Utvrđeni nivoi organskih zagađujućih materija u vodama reke Vjosa bili su niži od prijavljenih koncentracija za druge ekosisteme u Albaniji.

Ključne reči: reka Vjosa, organohlorni pesticidi, PCB, PAH, BTEKS, uzorci vode, GC/ECD/FID.

\author{
Naučni rad \\ Rad primljen: 01.07.2017. \\ Rad prihvaćen: 22.07.2017. \\ Rad je dostupan na sajtu: www.idk.org.rs/casopis
}

(C) 2017 Authors. Published by Inženjersko društvo za koroziju. This article is an open access article distributed under the terms and conditions of the Creative Commons Attribution 4.0 International license (https://creativecommons.org/licenses/by/4.0/) 